が成り立っているかの如さ印象を与える。 maisonnée, clan, lignage の相互関係に ついて炙亦り触れていない。しかし， こうした点は本韾のモノグラフィーと琶 丂性格加らして必然的な欠点と楞えるか

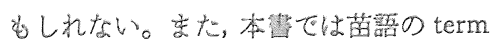
を蔡篦に使用するため，第 1 草の初的及

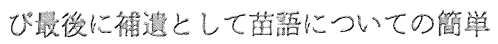
な解説がある。この大部分妒「中国少数

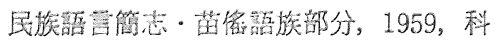
学出版社」からの引用であり, 何ら目新 らしいものはないが，获浯を漠藏藏グル ープの一つとした点，また挡䁚諭の分野 で，悬督終止についての解䣋に関卞る間 䫘など, 多少疑間の残る点もないとは言 充い。

な挌，蕃者 Jacques Lemoine 氏はフ ランス CNRS (图立科学研究所) の研究 员として㫤期に亘りラオスに滞在し, 現 在も現地で敦相研究に従事している。こ れまで苗及び傜族についての幾つかの 優れた諭文を発裴している。

〔新谷忠彦】

（連絡先 Takahiko Shintani, Maison de Norvège, $7 \mathrm{Bd}$. Jourdan, 75690, Paris, Cedex 14. France)

\section{Etudes Vietnamiennes}

No, 15. Régions Montagneuses et Minorités Nationales en R. D. du Vietnam.

Hanoi, 1967.

No. 32. Données ethnographiques. (1)

Hanoi, 31971.

ヴェトナムがフランスの支配下を離れ
ると共に，その少数民族，特に北ヴェト ナムに於ける少数民族についての犋辉は 殆ど入手できなくなった。然るに，近年 Etudes Vietnamiennes としてハノイで 出版されているシリーズの中の No. 15 及びNo. 32 には，北ヴェトナムの少数 民族の突態及びその层族学的研究情況が 紹介されていて大変に興味深い。

ヴェトナムに於いて，少数民族はその 占有する面樻の大きさとは迹に，殆ど歴 史の中には登場して来ない。こうした点 から見れば、ここで細介されている経済， 文化，工業等あらゆる分野に亘る少数民 族の地位向上への努力とヴェトナム民族 との間の交流の促進などは，歴史上画期 的な事でるう。本害では、ヴェトナム 独立遭動の中での少数民族の果した役割 とその変迩，また多数の少数民族の中か らタイ、バンキウ，ザオ(傜)，ミュオン についての民族誌及びその現状が紹介さ れている。残念ながら，本害は一般大棌 向に䁌かれたものであって，その内容は 必ずしも等門的に高度なものとは言えな い。しかし，ともかく少数民族の現状走 知るためには好適な書物であろう。また 戦時下にもかかわらず，その研究が休み なく続いている様子もらか肪え，今後の 研究成果の発表に期待したい。

〔新谷 忠彦〕 